Brock Education

Vol. 15, No. 1, 2005

\title{
The Case Study as a Method for Exploring Expert Music Teaching
}

\author{
Jane Saunders \\ Lakehead University and Fort William Collegiate Institute
}

\begin{abstract}
This article explains how the case study method was used in an exploration of the career of an expert music teacher. The contextual and holistic qualities of the case study are discussed. In addition, insider research and the situated knowledge of participants in this case study are considered, leading to a brief summary of the research findings and an explication of the expert music teacher.
\end{abstract}

\section{Resumé}

Cet article décrit l'utilisation de la méthode d'étude de cas pour explorer la carrière d'enseignante experte en musique. L'auteure explore les aspects contextuels et holistiques de l'étude de cas. Elle examine également les notions de recherche effectuée par une personne qui fait partie du contexte d'étude ainsi que le savoir situé des participantes et participants. Une présentation sommaire des résultats de l'étude et une explication de la notion d'enseignante experte en musique complètent le texte.

What is an expert teacher? How does the pedagogy of an expert differ from that of a novice? Why is the influence of an expert teacher critical in the development of both students and subject-specific programs? Expert teachers combine a myriad of competencies, areas of knowledge, and professional qualities. In the literature, expert teaching is defined by the degree to which teachers exhibit theoretical and practical knowledge about pedagogical philosophy and effective teaching behaviours together with a cluster of personality traits, such as an ethic of care for students and empathy. The study of expert teaching is important in the process of professional teacher education, as well as for providing information on best practices for teachers searching to improve their pedagogy and programs. Therefore, professional and career development, pre-service teacher training, and leadership structures are a few of the areas in the educational system that can benefit from the experience and

Jane Saunders (Ph.D), is currently Chair of Arts and Music and a classroom music teacher at Fort William Collegiate Institute in Thunder Bay, ON. She also teaches in the Faculty of Education at Lakehead University. 
pedagogical practices of expert teachers. In my doctoral dissertation, entitled The Sound of Music: A Case Study of Teacher Diane Garrett, I explored the experience and expertise of one expert music teacher using the case study method. In this article, a brief summary of the research is presented, with a focus on the case study design as the chosen method for this type of qualitative inquiry.

\section{The Situational Case Study}

The case study is a detailed, in-depth exploration of one setting, subject, set of documents, or events. The end result or research product of case study inquiry is heuristic, meaning that it leads the reader to an understanding of the case being explored. Merriam (1998) states that "a qualitative case study is an intensive, holistic description and analysis of a single instance, phenomenon, or social unit" (p. 21). As explained by Bresler (1992), "qualitative researchers have a great interest in the uniqueness of the individual case, the variety of perceptions of that case, and the different intentionalities of the actors who populate that case" (p. 67). By using the case study method, which involves the collection of data from multiple sources - interviews, documents, and archival data - a detailed and descriptive profile of the expert music teacher can be developed.

\section{Why a Case Study?}

In the field of music education, researchers have identified several common characteristics, teaching philosophies, and practices of the expert music teacher (Grant \& Drafall, 1991; Hendel, 1995; King, 1998; Madsen, 1990; Santala, 2001). These characteristics include a solid knowledge of the subject, the effective sequencing and delivery of material, the ability to create a classroom environment suitable for all students, enthusiasm, and high-intensity instruction. Turner-Bisset (1999) states that:

Teaching is a deeply complex, intellectual and practical activity. It is a creative act, in which the expert teacher selects from the store of expertise and repertoire of teaching strategies and representations, the most appropriate ones for her or his purposes. (p.53)

In a study of elementary music teachers, Taebel and Coker (1980) found that the teacher was the most important contributor to pupil learning. This finding was echoed by Barone: 
Teachers are the most faithful members of society. They take as a primary article of faith that they can profoundly influence their students. They believe fiercely and deeply that they can imbue their students with proclivities, tastes, sensibilities, styles of thinking, attitude, and values, and by doing this, deny the determinism lurking within genes of families. (2001, p. vii)

Although the phenomenon of expert teaching has been examined, Shulman (1987) states that "richly developed portrayals of expertise in teaching are rare" (p. 1). In order to learn more about the artistry of teaching, Tobin (1988) suggested that the classrooms of both exemplary and non-exemplary teachers need to be explored. Expanding our understanding of expert teaching in music, including both the concept of the expert teacher and the need for exemplary teaching in this particular area of the performing arts, may help to inform and improve practice (Abeles, 1987; Swanwick, 1984). Furthermore, Abeles (1987) argues that expert teachers are important, as they support both novice teachers and professional development. As well, expert teachers can influence the development of curriculum, programming, and teacher training. Because most of the existing studies of expert teaching are quantitative in nature, there is a need for a more holistic understanding of the expert music teacher in the qualitative context in order to examine more completely the personal and professional experiences of expert music teachers.

Understanding the experience and influence of an expert music teacher enhances the depth of knowledge and subsequently develops the concept of the expert music teacher in relation to social context, philosophy, and teaching methodologies. By using the case study method to investigate and document the phenomenon of expert teaching through a description of the traits, professional development, role, experiences, and influence of one expert music teacher, a deeper knowledge regarding the nature of an expert teacher was reached.

\section{A Case is Contextual, Bounded, and Holistic}

In conceptualizing this study, a case study design was chosen in order to provide an in-depth analysis of Diane Garrett, as an expert music teacher, and to discover and understand the complexities of her experiences framed by the context of expert teaching. In other words, the detail and breadth of a single case study was the most favourable method for exploring the expert teaching of one individual. Creswell (1998) stresses the importance of the setting or 
bounded set of circumstances in limiting the case selected for study. As stated by Stake (1995), a "case study is the study of particularity and complexity of a single case, coming to understand its activity within important circumstances" (p. xi). In this case study, I aimed to reveal the thoughts, motivations, and inner feelings of the participants in relation to the subject of the case study, bounded by the context of the study itself - the people, the places, and the events. Each factor in the participants' accounts in relation to all other factors relating to the research subject was explored simultaneously. In a situational case study, the phenomenon is examined and data are collected and analyzed from several points of view (Bogdan \& Biklen, 1998). Furthermore, the themes which emerged from the study are reflective of the multiple points of view of the participants, and participants' relationships with Diane Garrett, and the phenomenon of the expert teacher.

The case itself is limited by time and place, and has many interrelated parts which make up the whole (Stake, 1995). In terms of time period, this study focuses on the years 1991 to 2001, the last ten years of Garrett's teaching career. This decision was framed by two main parameters. First, Steffy et al. (2000) suggest that teachers develop to the expert level during the middle and final years of their career. Second, in order to facilitate the selection of participants and maximize their power of recall, the most recent 10 years was identified as the boundary period for this case study. In addition, my professional and collegial relationship with Diane Garrett developed within the past 10 years, which increased my familiarity with this phase of her career.

In terms of the place or setting for this case, Fort William Collegiate Institute is a small, predominantly academic school with a population of approximately 600 students over the study period. Because of the structure of the senior elementary program in Thunder Bay's schools, students do not take music as a discrete subject or have access to specialized teachers or equipment until grade 9. Despite this fact, the music program at Fort William C. I. continued to thrive through the study period, with approximately 150 students enrolled. The vast majority of students had no musical training prior to their entry into grade 9. Given the musical standards that were consistently achieved at Fort William C. I. in comparison to the larger schools in Thunder Bay, the importance of the expert teacher in this case and her influence on the students and the program is worthy of exploration.

In summary, this study explored the phenomenon of expert teaching through the case of one expert music teacher. As a result of the multiple and contextual views of the participants, the knowledge that was produced is representative of the whole set of experiences and expressed images and beliefs of the participants. This concept is referred to as situated knowledge. 


\section{Situated Knowledge of Participants}

As part of the qualitative case study, participants engaged in communication with the researcher that was reflective of their lived experience within the bounds of the case. Situational knowledge builds a structure of interpretive meaning which participants assign to their experiences. The data, which they provide, are situated within their individual and collective experiences, and as a result, are combined to form a wholly unique and evolving understanding of the research phenomenon. Lather (1986) refers to this specific communication as reciprocal because of its collaborative and interactive nature. Because understanding is negotiated in this type of qualitative case study, and because participants are viewed as positioned within the framework of the case itself, each participant brings and reflects on knowledge which is informed by his/her own perspective. As stated by Greene (1995), "we create our identities in the situations of our lives" (p. 51). In this particular case, or situation, the perspective represented by the participants is based on their experience with the primary participant, in the time period 1991 through 2001 at Fort William Collegiate Institute in Thunder Bay, Ontario. The meanings generated in this type of inquiry reflect participants' active involvement in the process of textual construction and validation (Lather, 1986). The participants were engaged in the creation of the text during the interview process and the validation of the text through the process of member checking. By encouraging self-reflection, the process allowed participants to change their perceptions, which can subsequently deepen their understanding of their particular situation or experience (Lather, 1986). Through their recollections and reflections on the expert teaching of Diane Garrett, participants' situated knowledge collectively contributed to the development of discourse and themes in this study.

\section{Insider Research}

In my researcher role in this study, I was also a participant, using the interview process to gather descriptive information from the participants to guide the development of a multi-layered, descriptive portrait of the primary participant. Because of the nature of this dialogic process, the researcher negotiated meaning with the participants through interview questioning and secondary data collection. Although teaching and learning behaviours can be understood as being constructed purposefully by the participants (Magoon, 1977), there was a need for me, as the researcher, to bracket or disclose my position and biases before and during the data collection process. The researcher must have tolerance for ambiguity, display sensitivity, and use intuition (Merriam, 1998). Denzin and Lincoln (1994) stress personal accountability and the value 
of individual expression and sharing of emotions by the participants. In this particular study, my relationship to the primary participant was one of teaching colleague, mentee, and friend, to the secondary adult participants, that of colleague, and in reference to the secondary student participants, that of teacher. It was important that I, as the researcher, acknowledged my preconceptions and theoretical beliefs as much as possible to better understand the participants' lived experience. By building in reflexivity, a practice in which I, the researcher engaged in explicit, self-aware analysis of my own role as an insider, and by using written observations, member checking, and critical peers (one arts education researcher and one teacher educator), I was able to better able to evaluate, manage, and also incorporate my role as an insider.

\section{Data Collection and Analysis}

In this case study, the participants, one primary and eight secondary (a combination of students, colleagues, and community members) were formally interviewed using a semi-structured format. Secondary participants were selected based on Patton's (1990) purposive sampling approach. I conducted seven interviews with the primary participant, ranging in length from 30 to 90 minutes in length. Secondary participants were interviewed initially for a period of approximately 45 minutes each. A follow-up interview took place with each of these participants in which topics of interest were further pursued and participants provided additional recollections after having a period of time to reflect on their interview. In keeping with the emergent nature of qualitative data collection, the open-ended research questions addressed topics flexibly, allowing for a natural flow of conversation. The interviews focused on the expert teacher's personal characteristics, teaching behaviours, pedagogical beliefs, interpersonal relationships, instructional strategies, challenges, peak experiences, and curriculum. Transcribed interview data were interpreted using van Manen's (1998) highlighting method of thematic analysis and formation of topics and themes. Interview data from the primary participant, combined with documents (lesson plans, personal letters) and archival data (cassette and video tapes) were used to form a biographical sketch, which provided the necessary background for the interpretation of findings and development of new knowledge. Because the case study method traditionally includes such biographical data, as in this study, a deeper understanding of the nature of this expert teacher and the philosophical underpinnings of her pedagogy was revealed.

Following the process of thematic analysis, which involved the highlighting of key phrases and statements, and the grouping of these phrases 
into common topics, three main themes emerged from the data. Each of these themes was named titled with a song from The Sound of Music which best represented its character and quality.

\section{Identifying New Knowledge}

Three themes emerged from this case study which represented the most enlightening and meaningful experience of this one expert teacher. Building familial relationships within the classroom, with the expert teacher as both a parental figure and a role model for excellence, was the first and most compelling theme which emerged from the data. Sixteen Going on Seventeen captured the concept of the people within the Fort William Collegiate Institute music department learning and growing together through the developmental bonds of a team or a family. Diane was recognized as the leader of the team, or the parental figure of the music family. Participants recalled that Diane "had such an influence over everything in your life", and that she was "like our Mom or kind of like the Mom of the music room." Creating bonds with students was of great importance to Diane, and her sincere interest in their development as students and musicians helped to establish an ethic of care in her classroom. As Diane explained, 'it's like your own family; you will give birth to new musicians, nurture them, heal them, enjoy life with them, celebrate their successes." Students acknowledged their evolution from junior to senior student and their responsibility as senior students to act as mentors to the juniors.

The music room was seen by students as their home base, the place where a sense of camaraderie and belonging was developed and nurtured through working and socializing together. Student participants felt they experienced a family-like atmosphere while "growing up" in the Fort William Collegiate Institute music department. Diane's leadership and caring concern for individual students, their academic performance, home life, and of course, their commitment to the program, provided a stabilizing and driving force. Parents of students were also an important part of the team, as they were also involved in the success of the Fort William Collegiate Institute music program. Music students, their siblings, and their parents were encouraged to fully participate in music department events, which added another layer of familiarity and comfort to school events. This type of community building was at the centre of the Fort William Collegiate Institute music department philosophy and activities.

With teaching and learning as the focus of program goals and class activities, the expert teacher in this case study combined striving for excellence 
in teaching and learning (Do-Re-Mi) and supporting students in their lives both inside and outside of the classroom. Diane's ability to teach to and meet the needs of individual learners was reported in many ways by participants.

One participant recalled that "she would always work with the weaker students to make them their best, too, because she knew that everybody could do it if they tried." Students appreciated the personal support that they received from Diane and her interest in their scholastic and musical development. As one student remembered, "she made me want to be a better person because I saw how much she enjoyed the music, so it made me want to enjoy the music too."

Furthermore, students enjoyed the many opportunities available to develop their group and leadership skills with their peers in the music program. The in-depth nature of case study research exposed such detailed findings through the re-iteration of shared experiences by the primary and secondary participants, were reflected in the archival data, and resonate with the researcher's own experience as an insider.

Enfolded in the experience of family and the emphasis on teaching and learning was the third theme of striving for excellence. This theme is based on participants' recollections about the influence and driving force of Diane, which they found both motivating and challenging. In order to maintain the high standards for which the music department at Fort William Collegiate Institute is known, high expectations for performance were placed on participants. As Diane stated, "a teacher who is in one school for many, many years develops a responsibility for maintaining [a high profile music program]." The students also had a role to play in maintaining these standards and contributing to the evolution of the music program. One student explained that "experiencing the rewards of success" and "experiencing what excellence felt like, through performance" provided the motivation needed for his dedication to such a demanding teacher and program. Through a combination of Diane's strength as a teacher and musical role model and student dedication, Diane and her students were clearly able to Climb Ev'ry Mountain. Through the last 10 years of her career, Diane promoted the Fort William Collegiate Institute music program on a large scale, including five mammoth Broadway musicals, school tours and trips, and numerous public performances, and she led the music students of Fort William Collegiate Institute to achieve extraordinarily high musical standards.

\section{The Expert Teacher - A Case Study}

This case study was used to explore the phenomenon of expert teaching through an examination of the career of one expert music teacher. Because of the rich detail provided by the participants, and the availability and use of 
secondary data sources, a multi-dimensional and complex portrait of one expert music teacher has been developed. The expert music teacher in this case study is an example of Elliott's (1995) praxial music educator, one who combines musicianship and educatorship and encourages learning and development in a natural musical environment. Diane Garrett's music teaching demonstrated a combination of subject-specific knowledge, personal and professional vision, role-modeling, and an ethic of care. Her role as a parental figure adds a new quality to the description or portrait of the expert teacher.

The importance of the expert teacher as an agent of teaching and learning in the classroom is paramount, regardless of subject area. Precise and specific information gleaned from this in-depth focus on this expert teacher's pedagogical, professional, and personal philosophy and long-term growth can inform teaching practice, pre-service teacher education, and future research on the phenomenon of expert teaching. Moreover, the expert teacher can act as a role model and mentor for colleagues at any stage of professional development.

\section{Conclusion}

Qualitative, descriptive data gathered during the interview process provided the basis for the complex and elaborate representation of this one expert teacher. The case study method enables vivid and vibrant description of a phenomenon from multiple viewpoints. In this case, the many components of the expert teacher's philosophy and pedagogy were explored simultaneously. This holistic approach enables the researcher to see the "whole picture" of the expert teacher, rather than strictly focusing on a quality-oriented or variable approach to the expert teacher's beliefs and behaviours. For example, the case study provides an alternative way to examine a behavioural routine, such as developing an in-class reward system for student achievement. By allowing participants to report on their experiences with this behavioural routine, a wider range of data is made available relating to the academic, social, and psychological impacts of such a behavioural routine. As a result, the researcher is able to integrate data from several sources about this one minute piece of the expert teacher's repertoire into to formation of the larger outcome - behavioural routines of the expert teacher, and to the overall phenomenon the expert teacher. Richly detailed accounts of expert teaching, developed through the case study method, provide an abundant resource of information and inspiration as embodied by the expert teacher. 


\section{References}

Abeles, H. (1987). The role of the master teacher in achieving professional excellence. Music Educators Journal, 73(6), 47-50.

Barone, T. (2001). Touching eternity: The enduring outcomes of teaching. NY: Teacher's College Press.

Bogdan, R., \& Biklen, S. K. (1998). Qualitative research for education ( $3^{\text {rd }}$ ed.). Boston: Allyn \& Bacon.

Bresler, L. (1992). Qualitative paradigms in music education research. The Quarterly Journal of Music Teaching and Learning, 3(1), 64-79.

Creswell, J. W. (1998). Qualitative inquiry and research design: Choosing among five traditions. Thousand Oaks, CA: Sage.

Denzin, N. K., \& Lincoln, Y. S. (1994). Handbook of qualitative research. Thousand Oaks, CA: Sage.

Elliott, D. J. (1995). Music matters: A new philosophy of music education. NY: Oxford University Press.

Grant, J. W., \& Drafall L. E. (1991). Teacher effectiveness research: A review and comparison. Bulletin of the Council for Research in Music Education, $108,31-48$.

Greene, M. (1995). Releasing the imagination. San Francisco: Jossey-Bass.

Hendel, C. (1995). Behavioral characteristics and instructional patterns of selected music teachers. Journal of Research in Music Education, 43(3), 182-203.

King, G. (1998). Exemplary music educator: A case study. Bulletin of the Council for Research in Music Education, 137, 57-72.

Lather, P. (1986). Research as praxis. Harvard Educational Review, 56(3), 257-277.

Madsen, C. K. (1990). Teacher intensity in relationship to music education. Bulletin of the Council for Research in Music Education, 104, 38-46.

Magoon, A. J. (1977). Constructivist approaches in educational research. Review of Educational Research, 47(4), 651-693.

Merriam, S. B. (1998). Qualitative research and case study applications in education. San Francisco: Jossey-Bass.

Patton, M. Q. (1990). Qualitative evaluation and research methods. Newbury Park, CA: Sage.

Santala, A. W. (2001). A phenomenological study of four exemplary music teachers in Northwestern Ontario. Unpublished master's thesis, Lakehead University, Thunder Bay, ON, Canada.

Shulman, L. S. (1987). Knowledge and teaching: Foundation of the new reform. Harvard Educational Review, 57(1), 1-22.

Stake, R. (1995). The art of case study research. Thousand Oaks, CA: Sage. 
Steffy, B. E., Wolfe, M. P., Pasch, S. H., \& Enz, B. J. (Eds.). (2000). Life cycle of the career teacher. Thousand Oaks, CA: Corwin.

Swanwick, K. (1984). Some observations on research and music education. British Journal of Music Education, 1(3), 195-204.

Taebel, D. K., \& Coker, J. G. (1980). Teaching effectiveness in elementary classroom music: Relationships among competency measures, pupil product measures, and certain attribute variables. Journal of Research in Music Education, 28(4), 250-264.

Tobin, K., \& Fraser, B. J. (1988). Investigations of exemplary practice in high school science and mathematics. Australian Journal of Education, 32(1), 75-94.

Turner-Bisset, R. (1999). The knowledge base of the expert teacher. British Educational Research Journal, 25(1), 39-55.

van Manen, M. (1998). Researching lived experience: Human science for an action sensitive pedagogy ( $2^{\text {nd }}$ ed.). London, ON: The Althouse Press. 